\title{
Gender and Patriarchy Issues in Women's Village Leadership and Women's Village Apparatus Domination in Plantation Community of North Sumatra
}

\author{
Harmona Daulay \\ University of North Sumatra \\ harmonadaulay@usu.ac.id \\ T.Ilham Saladin \\ University of North Sumatra \\ Ilhamsaladin@gmail.com
}

\begin{abstract}
This research seeks to find the phenomenon of increasingly widespread female leaders in government, politics and business / private field. We recognize that there are stereotypes that put women as the second-class citizens or in the domestic sector which are affected by patriarchal values that are still developing in Indonesia. This is due to the differences in parenting patterns from earlier age that cause women lack of skills and courage in leadership. There are interesting things in the phenomenon of women's leadership in Karang Baru Village, Talawi Sub-district, Batubara Regency, where the Head of Village and all the village apparatus are dominated by women.

The formulation of the problem in this research will reveal the reasons for being a leader and selecting village apparatus under her leadership who are also women. How does the femininity turns out as a leadership power. Another interesting point is that the oil palm plantation area in North Sumatra adds to the sociological complexity of the women's leadership issue, especially in Karang Baru village where most of the villagers work in oil palm plantations. This research uses qualitative method and collects data by doing an in-depth interviews. In-depth interviews were conducted with the female villages head and her female officers.

The results of the study finds that female leader undertook feminine and transformational leadership styles. Stereotype femininity called as fussy, meticulous and can perform various jobs (multi-tasking) is somehow the strength for the leader in running the village government. It can be seen from the two periods of the female leader' leadership, the continuous support from the female voters and also the male villagers as a whole.
\end{abstract}

\section{Keywords: Women Leaders, Local Patriarchy, and Plantation Society}

\section{BACKGROUND}

Most people in Indonesia assume that leaders in government and other public sectors are men. Meanwhile many women leaders has become the phenomenon of leadership in Indonesia in these two decades. We can see in the context of President
Megawati who led the period from 2001 to 2004. Also, the ministers in the cabinet of Joko Widodo which there are eight female ministers. The phenomenon of at least female leaders is not only in government but also in the business and private sector. Data showing gender discrimination is still experienced by Indonesian women in high-profile positions in business and private companies. McKinsey and Femina's survey of 500 working women occupying junior managers, executives, and CEO positions across Indonesia discloses the fact that 47 percent of half of the graduate respondents can hold positions at entry level. While at the middle management level, the share of women decreased and only left 20 percent. This amount is getting smaller at the level of directors, which is 6 percent at the level of directors and 5 percent in the position of CEO.

The increase in the number of women who lead the region is seen in the interim recapitulation, of 123 candidates for heads and deputy heads of women in 2015, at least 35 candidates are elected", said the Executive Director of the Association for Election and Democracy (Perludem) Titi Anggraini, on Rappler, Thursday, December 10. It becomes an exciting thing in the dynamics of the study of women leaders. Moving from the data and conditions of women leaders on a national scale, There is an interest in women's studies in local politics in North Sumatra. The phenomenon of women who lead at the local level as in districts and cities in Indonesia is a significant improvement. It is also interesting when women leaders emerge in the context of a village area.

The fact in Karang Baru Village in Talawi Subdistrict Batu Bara District is a unique phenomenon. In this village, the entire village government is led by women, from the leader to the officials. The research is expected to explain what is the reason for the village head's to become a leader and why dos she choose women to become the village officials. How 
does the female leader utilize the femininity side that becomes a force in the potential of women?

\section{THEORETICAL FRAMEWORK}

According to Karlis (1996), most Americans believe that women's employment opportunities are not the same, but they prefer to be led by male bosses rather than women. In the literature review above shows that women's leadership portraits are still on the feminine leadership style, yet many women are entering leaders at senior management level, as well as very few women entering top management. Based on this, research on women leaders in top management from village level is important to be understood.

In the Indonesian history, there were several women figures who were also the political leaders. First, Queen Kalinyamat who ruled in the kingdom of Jepara in Central Java around the year 1574. Second, Siti Aisyah We Tenreolle who has led the kingdom Ternate Sulawesi South in 1856. Thirdly, the women who reigned in Aceh for almost 60 years (1640-1999) respectively, such as the daughter of Sultan Iskandar Mudayang known as the First Queen of Sultanah Tajah Alam Syafiuddin Shah (1641- 1675), Sultanah Alam Naqaduddin Shah (1675-1678), Inayat Shah Zakiatuddin Shah (1678-1688), and Kamat Syah Zairatuddin Shah (1688-1699).

Women believe that women's skill capacity, access, and participation in politics is one way to penetrate the male leadership skills that are still dominating the political arena in Indonesia. The world notes that women can more easily master parliamentary level than the executive level. Hester Einstein (1991), a professor of sociology at Queens College, proposed three categories of women's intervention in the bureaucracy: the first category of 'bureaucratic-individual' interventions: women enter the government bureaucracy in policy-making levels as a feminist self-identities feminist).

The second category is 'bureaucratic-structural' intervention: women create new structures in government or administration designed to benefit women, both regarding empowerment, participation, and friendly women policy. The third category of other forms of feminist political intervention such as 'legal reform' through legislative change, political participation in leadership roles, presents themselves as feminist (self-proclaimed feminist) in trade unions and political parties, and in 'alternative structures' (alternative structure) in which feminists build independent organizations outside existing political and administrative structures.
In leadership studies, there are four styles of female leadership, firstly, a masculine leadership style which is accentuated power. Secondly, the feminine leadership style is characterized by being a caretaker for others and responsible for activities. Third, the transactional leadership style, that is, the more exchanged relationships The four styles of transformational leadership, namely the leadership style on change is better.

This paper will use feminist theory in raising gender issues in women's leadership. The word "eco" in ecology comes from the Greek Oikos, which means the home of all women and men, animals, plants, water, soil, air, and sun. The theory of ecofeminism is assumed to see individuals more comprehensively, as being bound and interacting with their environment. At the beginning of the concepts eco-feminist look at women's issues in participation with the surrounding natural environment.

The interesting thing about this eco-feminist study is that its criticism of what happens in women's emancipation is that when women enter the masculine world once dominated by men, it no longer accentuates its feminine qualities, but instead becomes a male clone and entering into a hierarchical masculine system trap. The entry of women into the masculine world (the public world generally) has led to a more dominant modern civilization colored by masculine qualities. Consequently, what is seen is competition, self-centered, domination, and exploitation. The real examples of the fading mirrors of feminine quality (love, nurturance, and nurturance) in society are the increasing destruction of nature, the increasing crime, the decline of social solidarity, and the increasing number of women who abandon their children.

This is a relevant eco-feminist note in the context of this study. How does the village (woman) leader make various approaches in leading the community? The approach is done by practicing the value of femininity. The value of femininity as women are more concerned, more detail, and neater.

\section{RESEARCH METHOD}

This research uses qualitative research method. The research corpus is the female village head and female village apparatus and the head of the PKK and other women's tools. Informant research amounted to 10 people. Data collection was conducted by doing interviews with key informants and additional informants. In addition to interviews, focus group 
discussions were also conducted to complete the existing data deficiencies.

\section{RESULT AND DISCUSSION}

\subsection{General Overview of Karang Baru Village, Petatal Sub-district, Batu Bara District}

Batu Bara District is one of the districts in North Sumatera Province that was formed in 2007, which is an expansion of Asahan District. Batu Bara District is located on the East Coast of North Sumatra region bordering the Malacca Strait. Batu Bara District occupies an area of 90,496 hectares consisting of 7 Sub-districts and 100 villages.

Karang Baru Village is one of the villages among nineteen villages and one village in Talawi Sub-district, Batu Bara District. The village of Karang Baru was formed on the 19 th of April 1994, the result of the split from the village, namely Petatal Village. The total population of the village of Karang Baru Talawi Batu Bara District is 2,782 people, consisting of 747 families. The male population is 1,331 souls, and the female population is 2,782 inhabitants. From the monograph data, it appears that the number of female population is more than the number of male population.

\subsection{The Role of Women in Village Leadership}

In Karang Baru village when their village head is led by women for two periods shows the debate of women may appear as a leader. When we quote from a Mernissi, who saw that women's rights in leadership were essentially a small part of the political rights that every human being must have, as the right to represent women in the general society, the right to a decent job in accordance with its capacity, the right to the protection of the state, the right to equitable treatment in law and other rights, all of which are within the scope of human rights.

Karang Baru Village in Talawi Sub-district Batubara District is a village surrounded by oil palm plantations. The social system of the plantation community greatly influences the daily life of the people. The dominance of the Javanese tribe became the reference to life and tradition in this region. Within a decade the leadership of the village head was led by a woman. The village equipment also consists of 6 people as well as women. The number of hamlet heads as many as six people. The thing that attracts the hamlet heads are all men.
Harmonious working relationships of female village heads with female village apparatus as well as male heads of men are seen to show the performance of this village. This is evident from the use of village budget funds (ABD) that are examined and become role models for other villages nearby.

The leader of the village of Karang Baru named Mrs. SA and she has led for two periods, from 2006-2012 and 2012-2018 period. She, in the eyes of the village officials, is considered very wise to carry out leadership. Before becoming a village head, she was a teacher and was actively involved in community activities. She is the wife of the head of Karang Baru Village before. The key to her victory is the number of women's votes who chose her. Women voters are also very gender biased because they choose Mrs. SA as she is a woman. As one of the informants of village women informants stated that:

"because if woman is the leader she will be more carefully, more concerned with the community. Another guy with a man. If it's a man, just what's okay if someone is reporting it is up to where it's good. If women are more deeply into the problems in this village. (Eva Village Employees Interview)"

The village head (the Mrs. SA) also choose village apparatus, the village secretary who are also women. The reason Mrs. SA chose women as the official staffs because they are deemed to have the appropriate competence. Competence according to this case is related to the stereotype of women who are accustomed to working related to administration and office. Women in the administration is considered as neat and thorough.

This is different from the village heads consisting of six hamlet chiefs led by men. There, men are more suited to work in the field. In addition to this, the hamlet chiefs also admitted that they lack skills in the administrative field. It is as stated by the head of village B which states:

"we feel that we are not harmed by accepting Mrs. SA as the leader., and there is a division of labor that woman is in the office and men in the field and until now we enjoy more field work that directly comes into contact with society".

From the above statement shows there is a division of labor between female employees in 
the village office and the male head village in the area (field). This shows the willingness of hamlet heads who feel they have no computer skills and other administrative skills. So that the placement of women in the appropriate place with the ability to be precise.

In the study of leadership patterns, Mrs. SA leadership can be categorized as a leader who utilizes feminine style mixed with the transformational style. This is related to the emphasis on the sense of motherhood as well as highlighting the femininity like the concept of nurturing which is played by SA as a mother. Maternal roles is an active role in social activities such as in the event of death. Mrs. SA also always doing her social work before she takes office. This role has benefited the village head electoral process. Many years of community work provide concrete evidence and campaigns for the electoral voice.

\section{WOMEN'S LEADERSHIP STYLE IN ECO- FEMINIST ANALYSIS}

Women's leadership style in the context of local governance in Karang Baru village is important to be analyzed related to how Mrs. SA perform various duties in performing the role to village. Leading the village with $48 \%$ of men is a challenge. Mrs. SA's way of leadership is making an approach in social activities and implement the village administration quickly and conduct joint deliberation for the implementation of village finances.

How does this Mrs. SA leadership relate in the context of feminism? Feminism appears to respond to the problem of gender inequality, discrimination, oppression, and violence against women. Feminism and ecological movements have mutually reinforcing goals, both of which seek to build a worldview and practice that is not based on models of domination. In a further study, the objectives of eco-feminist ethics have at least built theories and practices that pay attention to human and non-biased environmental environments. Eco-feminist at first did speak how women are close to nature, and the natural world is played like women.

How women's study in local village politics can be linked to eco-feminism? This is related to the mother in the village of Karang Baru as a symbol of politics and the mother who protects the community. Eco-physics agree that to take on male gender-biased roles; it is not necessary that women should be equal to men. Feminine roles in which the mother is considered to have various powers such as nurturing, caring, more responsive and meticulous as an important asset to enter the local politics by becoming the head of village.

The feminist and gender perspective sees that the female leader is weak, whiny, emotional and so forth. It turns out that by the nature of women it gives a positive value in leading because the leader is able to understand what happens in the community, more sensitive.

Mrs. SA used this side as a capital to lead the community.

In the stereotype study, women are considered as full of emotional sides. It turns out this stereotyping makes women better in carry out various financial handling. It is related to women as economic managers in the household. This also continues in other public sectors when women are considered better and deft to take care of village funds, mosque funds and so on. As disclosed by informants M "since our head of village is female, the internal drafting files are getting neater than ever before."

Stereotypes of women with various domestic, public and societal roles also makes women more effective in using the time to take care of the household. This is as expressed by the informant "if his fathers kind of anymore right, Wirid at 10 o'clock home at 11 ordinary it mam, stop by there drop by here meet a lot of friends, if the mothers where coming home Wirid already come home".

Data and facts show that the stereotypes and the strength of women's femininity turn out to provide capital in leadership in this Karang Baru Village. This is seen with the strength of Mrs. SA as a leader and can carry out roles so that it can take the office for two periods.

\section{CONCLUSION}

The gender stereotype seeing woman as weak and emotional are false considering the phenomenon of women leadership in Karang Baru Talawi Subdistrict. The combination of feminine and transformative leadership styles becomes the key leadership of the village head of Karang Baru, Mrs. SA. The ability of Mrs. SA to lead has undergone a shift from a rooted patriarchal culture to a sense of equality between men and women.

Eco-feminist theories become the key factor that does not make women into masculine politics into a male clone. Women can even maintain their femininity until it reaches the top position in a village far from national political power. If gender mainstreaming becomes a program of the Indonesian government to realize equality in Indonesia, this new Karang Baru village can be seen as an example. 


\section{References}

[1] Bystydzienski, Jill, 1992, Women Transforming Politic, Bloomington, Indiana University,

[2] Bogdan, Robert dan Steven J. Taylor1985 : Pengantar Metode Penelitian Kualitatif , PenerbitUsaha, Surabaya,

[3] Budiharjo, Miriam, 1992, Dasar - Dasar Ilmu Politik, Jakarta, PT. Gramedia,

[4] Bungin, Burhan, 2007, Metode Kualitatif, Kencana, Jakarta.

[5] Dewi, Machya Astuti, 2009, Potret Anggota Legislatif Perempuan di Provinsi Daerah Istimewa Yogyakarta Antara Misi dan Kapasitas Personal dalam Gender and Politic, Tiara Wacana Yogyakarta

[6] Fakih, Mansour, 1997, Analisis Gender dan Transformasi Sosial, Pustaka Pelajar, Yogyakarta

[7] Febriasih, Happy Budi dkk (edt), 2008, Gender dan Demokrasi, Averroes Press, Malang,

[8] Hadiz, Liza (edt), 2004, Perempuan dalam Wacana Politik Orde Baru, Pilihan Artikel Prisma LP3ES, Jakarta, 2004

[9] Halkes, Chatarina, J.M. 1991, New Creation, (Kentucky Wesminster: Wesminster/John Knox, Press

[10] Hasibuan, Aziarni, 2009 Perempuan Harus Berjuang Makin Gigih, harian Waspada 17 Maret 2009.

[11] Humaidah, Lisa Noor, 2012, Affirmative action dan Dampak Keterlibatan Perempuan: Sebuah Refeksi, Jurnal Perempuan 75.

[12] Isshiki, Yosiko, 2000, Eco Feminism in the 21 Century" dalam In God's Image Vol 9 no 3

[13] Jackson, Stevi dkk, 2009, Pengantar Teori-Teori Feminis Kontemporer, Jalasutra, Yogyakarta, 2009.

[14] Miles, Matthew B dan Michael B. Huberman, 1984 Qualitative Data Analysis: A source of New Methods. Sage Publication, London.

[15] Pambudy, Ninuk Mardiana, 2009. Keputusan MK Meluaskan Jangkauan Ke Luar Zona Aman, Harian Kompas, 30 Maret 2009.

[16] Partini, (2014), Partisipasi Politik Perempuan Dalam Praktik Kewarganegaraan di Indonesia, dalam Jurnal Perempuan Vol. 19, No. 2, Hal 41-43, Yayasan Jurnal Perempuan, Jakarta.

[17] Ricklander, Louise, 1993Women and Politics dalam Jenny Firth - Cozens and Michael A West (eds), Women at Work: Phychological and Organizational Perspective (Philadelphia: Open University Press,

[18] Sarantakos, 1993, Social Research, Meulbourne University Press,

[19] Shanti, Budi, Kuota Perempuan Dalam Parlemen, Jalan Menuju Kesetaraan PolitikJurnal Perempuan No. 19
[20] Scott, A, McEwen, 1986, Women In Industrialization: Examining The Female Marginalisation Thesis. The Journal of Developmen, Studies 22.4

[21] Subono, Nur Iman,, 2003 Perempuan dan Partisipasi Politik, Yayasan Jurnal Perempuan dan The Japan Foundation Indonesia ( JFI), Jakarta

[22] Soejipto, Ani, 2005, Politik Perempuan Bukan Gerhana, Jakarta, PT. Gramedia, Undang - Undang Pemilu : Implikasinya Untuk Perempuan,

[23] Surbakti, Ramlan, 1992, Memahami Ilmu Politik. Jakarta, Pt. Gramedia,

[24] Tan, Mely G, 1995, Perempuan Dan Pemberdayaan (Makalah dalam Kongres Ikatan Sosiologi Indonesia (ISI)), Ujung Pandang.

[25] W, Dorothy dan Tony Bernay, 1999, Women In Power, Perempuan dalam Kekuasaan Politik Jakarta, PT. Gramedia

[26] Wahyuni, Sri dan Hedwigis Esti R, 2009 Pandangan Publik tentang Keputusan Perempuan dalam Kancah Politik di Indonesia dalam Gender and Politic, Tiara Wacana Yogyakarta

[27] Warren, Karen, 1996, "Ecological Feminist Philosophies An Overview of the Issues, dalam Karen J, Warren (ed), Ecological Feminist Philosophies (Bloomington \& Indianapolis University Press hal xi

[28] Jurnal Perempuan No. 19, Penerbit Yayasan Jurnal Perempuan, Jakarta, 2001

[29] Jurnal Perempuan No 21, Penerbit Yayasan Jurnal Perempuan, Jakarta, 2002

[30] Jurnal Perempuan No 75, Penerbit Yayasan Jurnal Perempuan, Jakarta, 2012

[31] Jurnal Perempuan No 81, Penerbit Yayasan Jurnal Perempuan, Jakarta, 2014

[32] Subono, Nur Iman, (2012), Femocrat: Kritik Feminis dan Representasi Birokrasi, dalam Jurnal Perempuan, Vol. 17, No. 4, Hal 17. Yayasan Jurnal Perempuan, Jakarta.

[33] Sundari, Ayu, (2014), Politik Berbasis Komunitas: Pemberdayaan Perempuan Pemimpin di Yogyakarta, dalam Jurnal Perempuan Vol. 19, No. 2, Hal 133, Yayasan Jurnal Perempuan, Jakarta.

[34] Rahayu, Angger Wiji, (2012), Mitos, Data dan Fakta Perempuan Pemimpin, dalam Jurnal Perempuan, Vol. 17, No. 4, Hal 68. Yayasan Jurnal Perempuan, Jakarta. 